\title{
Two Dimensional Evolution Modeling of Source Rocks in the Chaluhe Basin, Yitong Graben
}

\author{
Obed Kweku Agbadze*, Jiaren Ye, Qiang Cao \\ Key Laboratory of Tectonics and Petroleum Resources, China University of Geosciences, MOE, Wuhan, China \\ Email: *t2text@yahoo.com
}

How to cite this paper: Agbadze, O.K., Ye, J.R. and Cao, Q. (2017) Two Dimensional Evolution Modeling of Source Rocks in the Chaluhe Basin, Yitong Graben. International Journal of Geosciences, 8, 801-810. https://doi.org/10.4236/ijg.2017.86045

Received: March 31, 2017

Accepted: June 18, 2017

Published: June 21, 2017

Copyright @ 2017 by authors and Scientific Research Publishing Inc. This work is licensed under the Creative Commons Attribution International License (CC BY 4.0).

http://creativecommons.org/licenses/by/4.0/

\section{c) (i) Open Access}

\begin{abstract}
Yitong Graben in Jilin Province of China, hosts three basins, namely: Chaluhe, Luxiang and Moliqing basins. The Chaluhe basin, as the focal point of this study has five subdivisions, thus, Bo-Tai sag, Wanchang Structural high, Liangjia Structure high Xinanpu sag, and the Gudian slope, with a cumulative sedimentary rock thickness of about 6000 metres. The basin is supposed to be a potential hydrocarbon-producing basin with its better source rock distribution and more favorable maturation indicators than the adjacent Luxiang and Moliqing Basin. Determining whether the mudstone beds present in the Eocene Formations are matured enough to generate hydrocarbons, three (3) wells with Seismic Lines (clh02, clh05 and clh07) were used for the study. It is observed that the entire region from NW to SE in the source rocks is mature to produce oil and gas. At depths of about $2400 \mathrm{~m}$ and below show good maturity with vitrinite reflectance values averaging $1.02 \%$ Ro. The Eocene Shuangyang mudstone is the main petroleum source rock.
\end{abstract}

\section{Keywords}

Petrophysics, Petrochemicals, Hydrocarbons, Eocene Mudstone, Chaluhe Basin, Yitong Graben

\section{Introduction}

The Yitong Graben which lies between Changchun city and Jilin city in the Jilin province contains the Moliqing, Luxiang and Chaluhe basins (Figure 1). The focus of this study is on the Chaluhe basin with five subdivision namely: the $\mathrm{Xi}$ nanpu sag, the Wanchang structural high, the Bo-Tai sag, the Gudian slope and the Liangjia structural high.

The Chaluhe Basin has experienced two episodes of uplift between 24.9 - 19.1 Ma and 6.9 - 4.9 Ma, with an average apparent exhumation rate to be 70.34 based on apatite fission track analysis of few basin samples, the results of which, can 


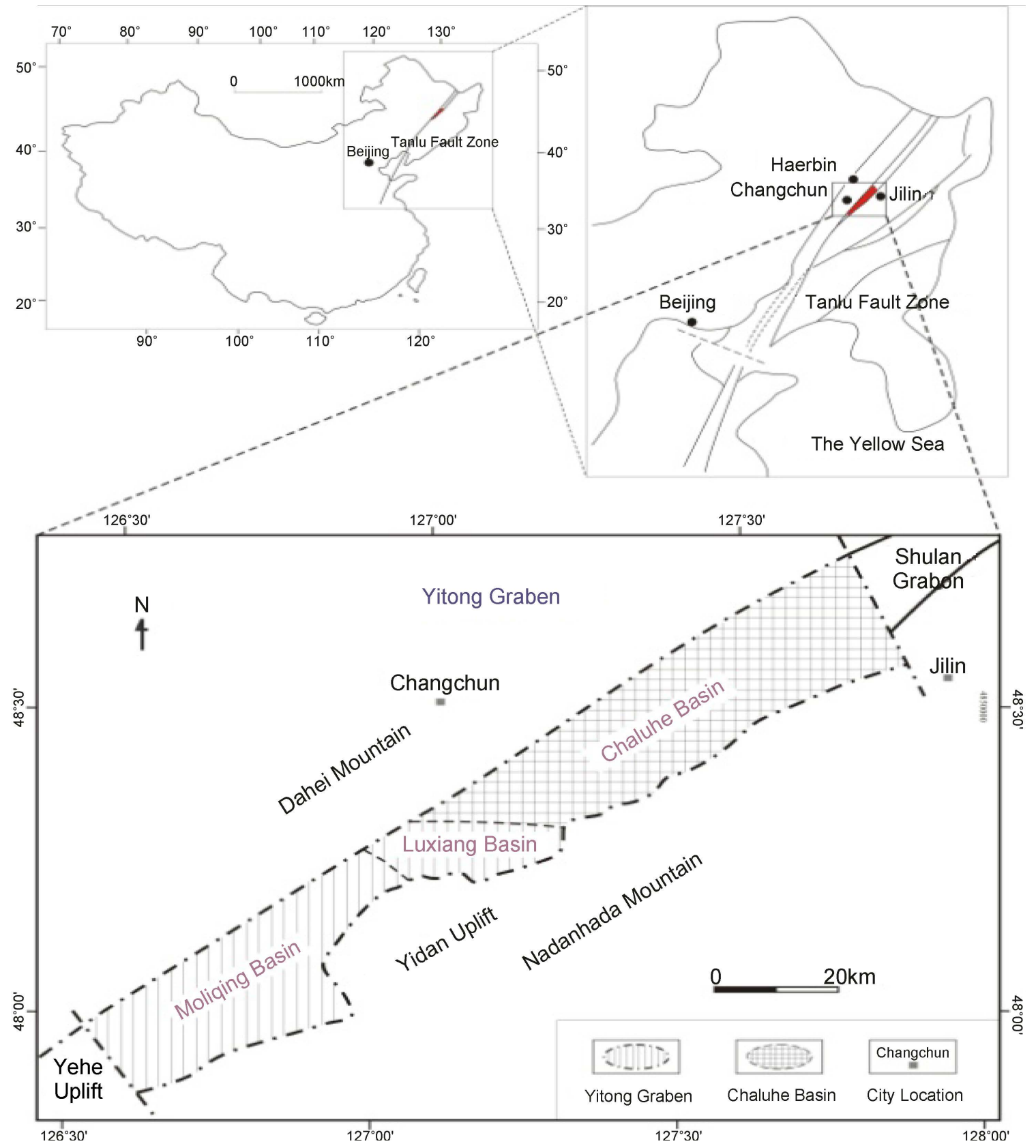

Figure 1. A map showing the loction of the Chaluhe Basin.

also be supported by the evidence from geological relationships such as geodynamics, volcanic activity, and stratigraphic division and correlation through thermochronological analysis [1].

Hydrocarbon exploration within the Chaluhe Basin has been unsuccessful with only local hydrocarbon producing shows discovered. On the other hand, SW part of Yitong Graben, housing the Moliqing and Luxiang basins have reserves of $3317 \times 10^{4} \mathrm{t}$ oil and $13.29 \times 10^{8} \mathrm{~m}^{3}$ gas. Interestingly, similar Cenozoic sediments and tectonic setting exists in all the basins, with the Chaluhe basin having widespread distribution of better source rocks and more favorable condition of hydrocarbon accumulation suggesting the Chaluhe Basin has a great po- 
tential of hydrocarbons.

The thermal history and petroleum generation of the Chaluhe Basin has been studied. Nevertheless, the models used to describe the basin thermal scenarios where not calibrated using the measured vitrinite reflectance, considered the major thermal indicator, because of the questionable measured values.

\section{Geological Settings}

The formation and development of the Yitong Graben mainly resulted from the collision between the Indian plate and the Eurasian plate, and the subduction of the Pacific plate to the Eurasian plate [2], trending NNW during the Early Eocene. During this period, three reverses and uplifts occurred in the Middle Eocene, Late Oligocene and Late Miocene [3].

The Yitong Graben is a petroliferous late-Mesozoic and Cenozoic slip-extensional basin located at the north east of China between the cities of Changchun and Jilin. This basin makes part of the Tanlu fault zone which is one of the largest continental strike-slip faults in the world [4].

The Yitong Graben is an oil-bearing geological structure with unique characteristics and encompassing the Moliqing, Chaluhe and Luxiang basins in Northeast China.

Based on Evidence from geodynamics background, the tectonic stress field of the Yitong Graben changed from tenso-shear to compresso-shear during the Cenozoic [5], which is related mainly to the alteration of subduction direction from the Pacific plate to the Eurasian plate [2]. The subduction was diagonally conducted from the Pacific plate to the Eurasian plate in direction from SSE to NNW during the Early Eocene, which resulted in the formation of the Yitong Graben. However, the subduction direction of the Pacific plate to the Eurasian plate has changed into EW direction since the Oligocene, which resulted in a series of phenomena related to compression stress field such as the thrust-motion of Tanlu fault zone [6], regional uplift, and intense folding and deformation within the Wanchang-Qijia formations in northwestern Yitong Graben.

\section{Materials and Methods}

\section{Materials and Input Parameters}

The BasinMod 2-D modeling used 1-D well data [7], Seismic Lines (clh02, clh05 and clh07) (Figure 2), map coordinates, reference location of all data including faults, names and age ranges of all layers, and lithologic characteristics of facies within the layers (Figure 3). Basin Mod 1-D transient heat flow values are the input parameters for the Basin View.

\section{Result Interpretation and Discussion}

This study analyzes Present Day two dimensional (2D) cross-sectional models. These maturity maps were developed employing the same parameters as discussed earlier in this study. 


\section{The Chaluhe Basin}

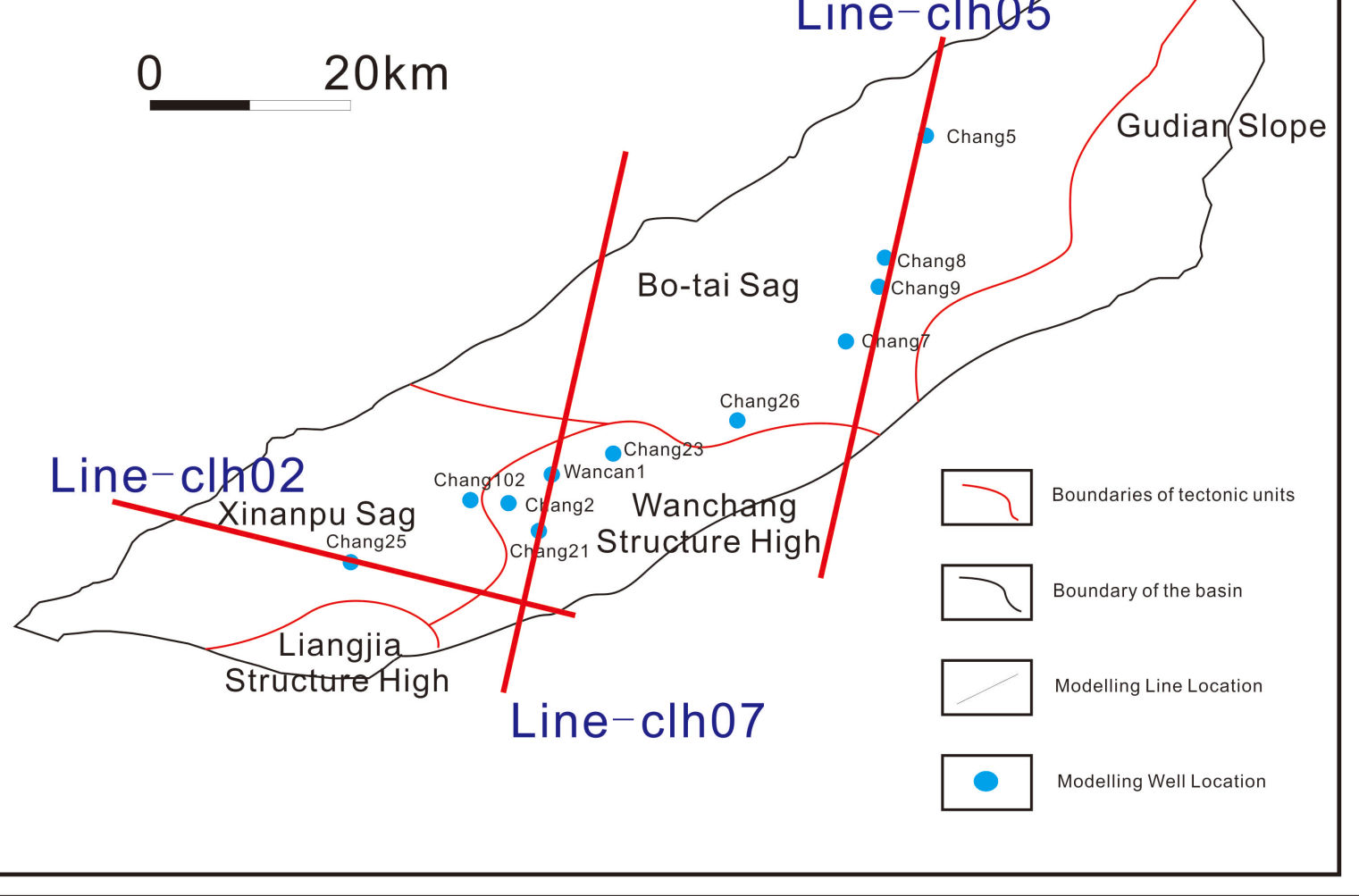

Figure 2. A map showing the Wells, Seismic lines for this study and the subdivisions of the Chaluhe Basin, the Yitong Graben.

\section{Thermal Maturity Results}

\section{Calibration and Analysis}

The capacity of the model to reproduce the thermal settings of the basin is influenced by the seismic lines recollection and their conversion to depth lines, and the model calibration based on the maturity indicators.

The basin stratus geometry is interpreted through the recollection of the formation seismic spectrum. Therefore, the data gathered is susceptible to errors related to the equipment and technique. Additionally, a conversion is required to turn the seismic data into depth data. For the Chaluhe basin, both, the recollected and the conversion equation were provided by the Jilin oil company and their validation is not feasible.

Regarding the conversion equation proposed by the Jilin oil company (equation X), its implementation produced depth lines that in most of the cases did not match with the strata depth recorded during the well drillings. This incongruence was corrected by displacing the curve vertically until the modeled line and the measured strata location at the well's position matched. Nevertheless, in some cases, once the depth line at the wells' location was relocated, the formation boundaries crossed between each other at other position, requiring further modifications. If the location of the seismic profile based depth lines do not correspond with its real location, the differences in depth could affect the modeled 


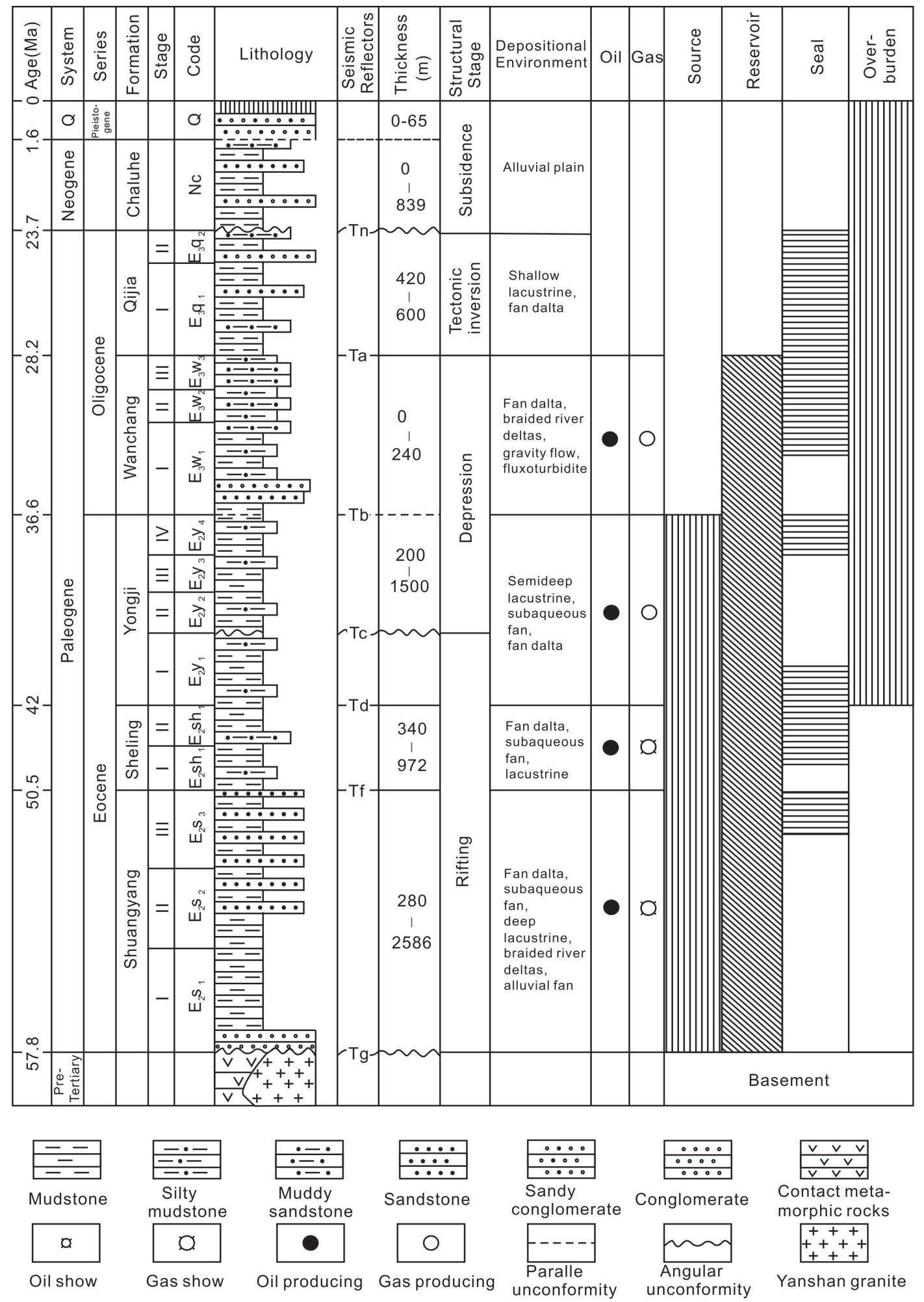

Figure 3. Stratigraphic columns in the Chaluhe basin detailing the lithology and rock types.

temperature profile, reducing the capacity of the simulation to describe the basin thermal characteristics.

Once the basin geometry is defined, the thermal settings of the area are simulated and calibrated using the well's measured geochemical data. However, as it 
was mentioned earlier, the inexistence of reliable thermal indicators made unviable further adjustment of the magnitude of the heat flow. For this reason, the heat flow calculated with the BasinMod 1D [7], that are consider the most reliable and precise results, were used, to constrain the model.

Due to the lack of reliable geochemical data and methods to estimate the thickness of the Shuangyang formation, the thermal maturity evaluation of the Chaluhe basin source rocks has not been conclusive. Nevertheless, from the modeled 2D seismic lines it is observable how the generative potential of the basin increases from the Yongji formation, to the Shuangyang.

The verification of the time-depth conversion equation is enhance in order to increase the precision of the modeled geometry and faults distribution of the ba$\sin$.

From the $2 \mathrm{D}$ modeling result, the following conclusions could be drawn from the present day temperature and maturation seismic cross sections;

1) In temperature cross section of seismic line 5 (Figure 4) in the Chaluhe basin, the temperature increases with increment in depth but differ in the various basin subsections. Trending, NW to SE with decreasing temperatures towards the SE sections. Similarly, following the temperature tendency, the maturation of the source rocks also encounters a higher maturation level towards the deeper locations. Present Day maturity profile of this seismic region (Figure 5) indicates that the two major source units, Shuangyang and Sheling formations are mature within certain maturity windows at particular depths. For these units, it is important to reiterate that the entire region from the NW to SE in this seismic line 5 is mature to produce hydrocarbons, but at varying maturity windows. At depths of about $2400 \mathrm{~m}$ and below, show good maturity with vitrinite reflectance values averaging $1.02 \%$ Ro. The Bo-Tai sag of this source unit has the highest
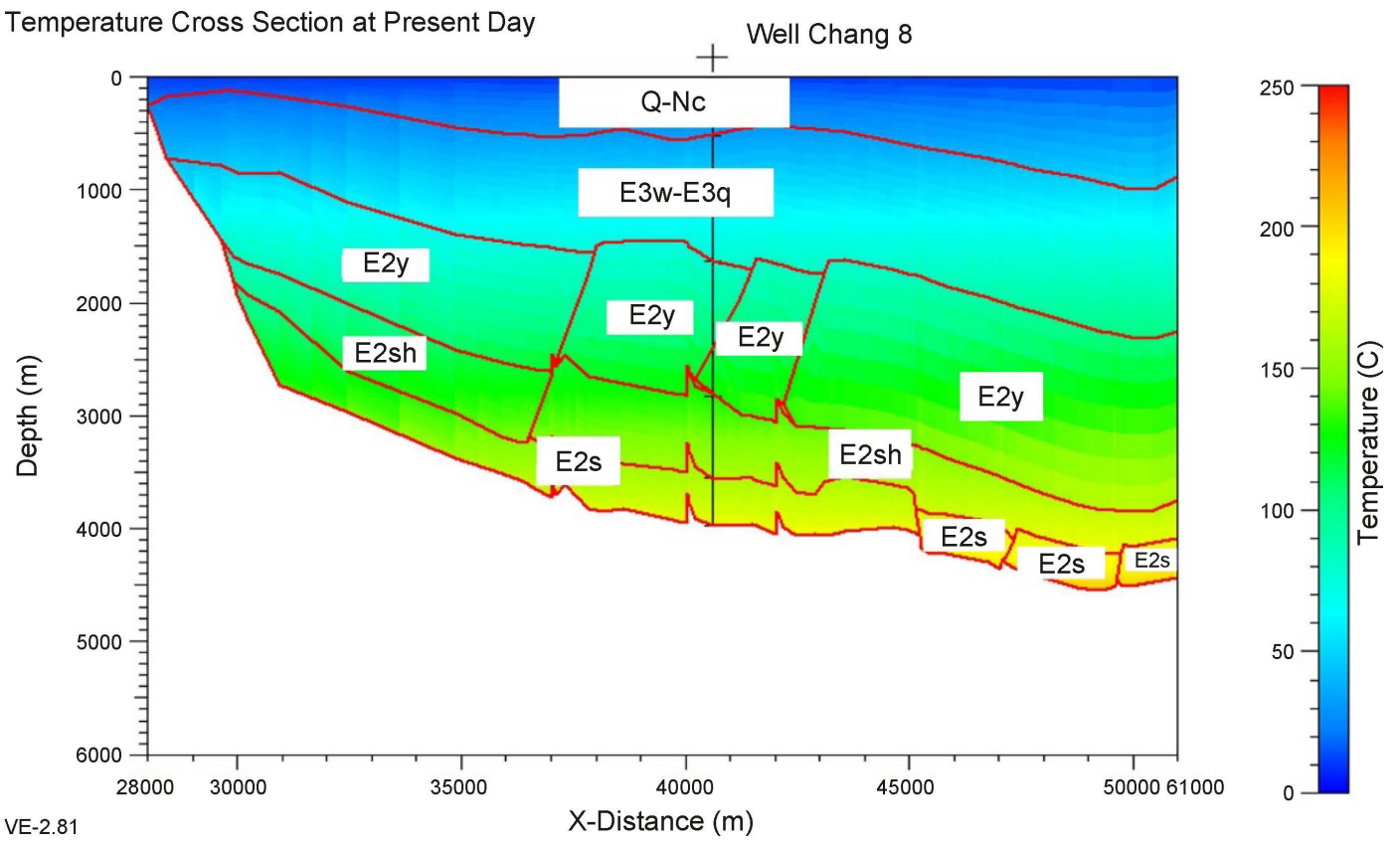

Figure 4. 2D present day temperature cross section profile of seismic line 5 . 
generative capability. Vitrinite Reflectance (Ro\%) values reflect values between $0.73 \%$ and $1.24 \%$; well still within the Gas window if calibrated against a conventional Ro\% scale.

2) The Present day Temperature of seismic profile line 7 (Figure 6) depicts similar characteristics, with higher temperatures at deeper depths. Generally good for maturation of the source rocks. In the above figure, the Lower Eocene source lies within the Oil window at depths of $2400 \mathrm{~m}$ and below but enters the peak gas phase at $3217 \mathrm{~m}$ with Ro (1.3\% to $1.77 \%)$ and the dominant source rock

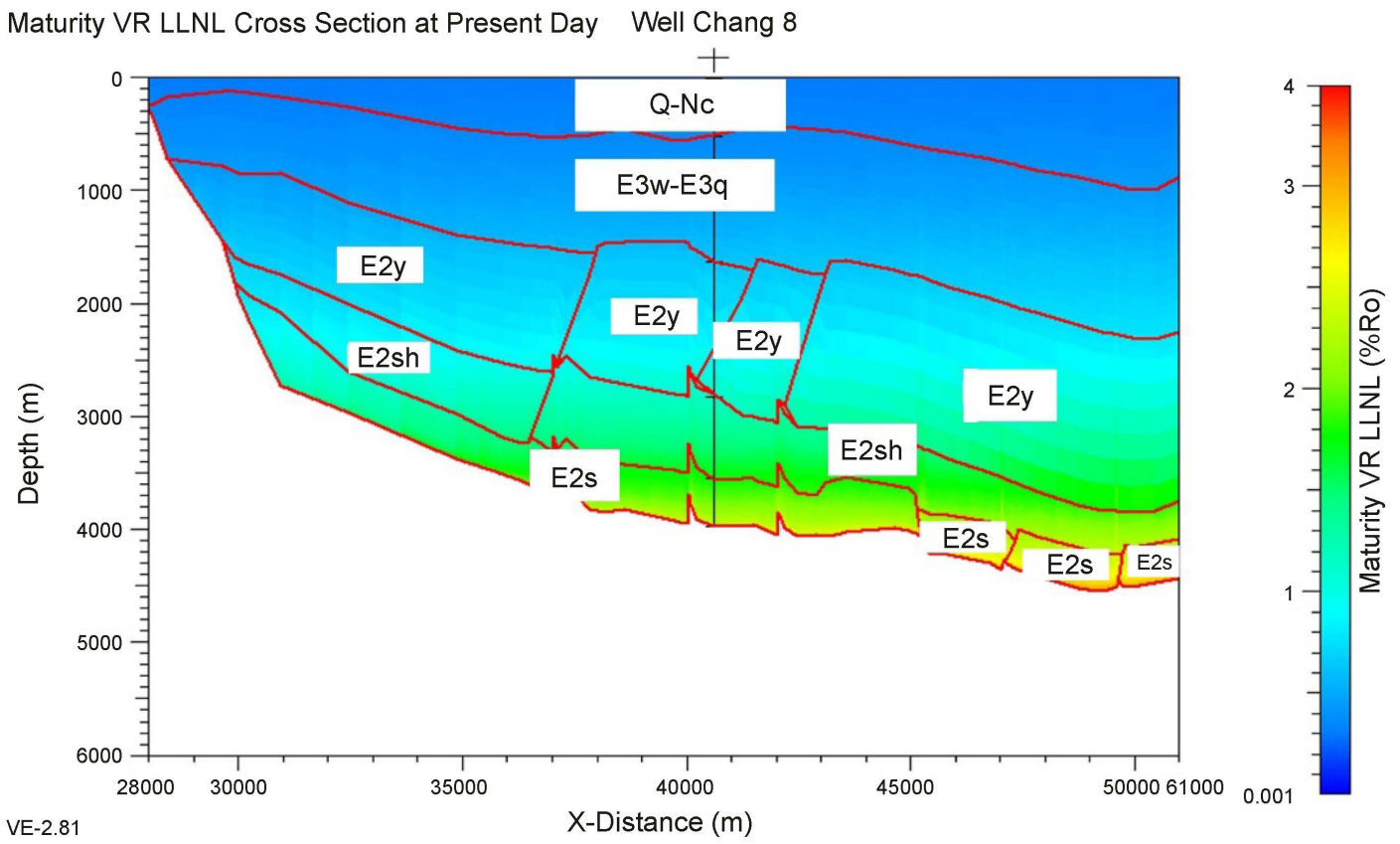

Figure 5. 2D present day maturity cross section profile of seismic line 5 .

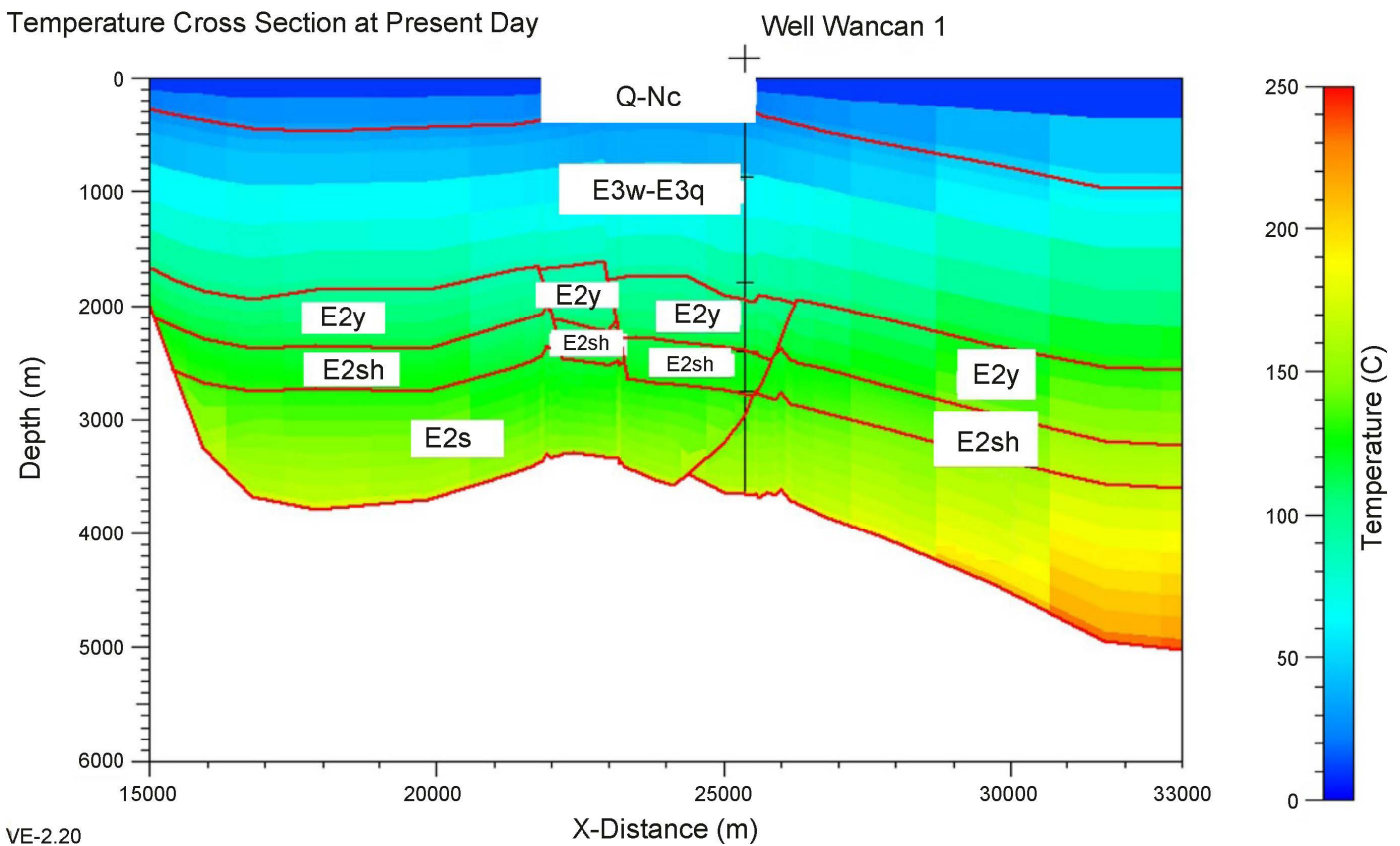

Figure 6. $2 \mathrm{D}$ present day temperature cross section profile of seismic line 7 . 
been the Shuangyang formations with mudstone as the source rock. The upper Eocene source, thus, the Sheling formation source is mainly in the oil window (Figure 7).

3) The seismic cross section profile for present day temperature of line 2, shows a more widely and balance temperature in the basin's lithologies but with slightly higher rates towards the NE (Figure 8).

This seismic line 2 reveals from the maturation profile (Figure 9) the source been mainly Upper Eocene formation. Below $2337 \mathrm{~m}$, Eocene formation shows

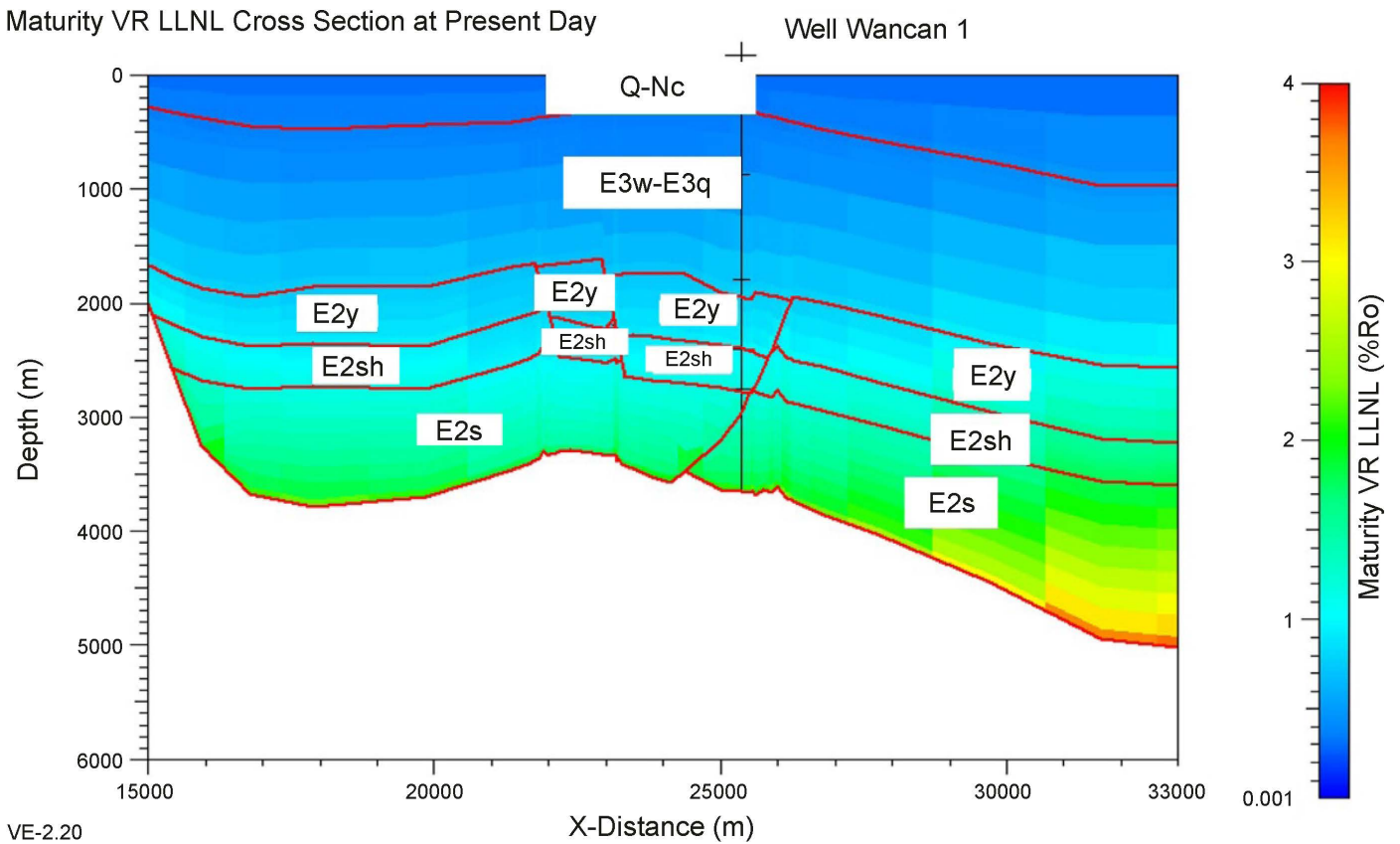

Figure 7. 2D present day maturity cross section profile of seismic line 7 .
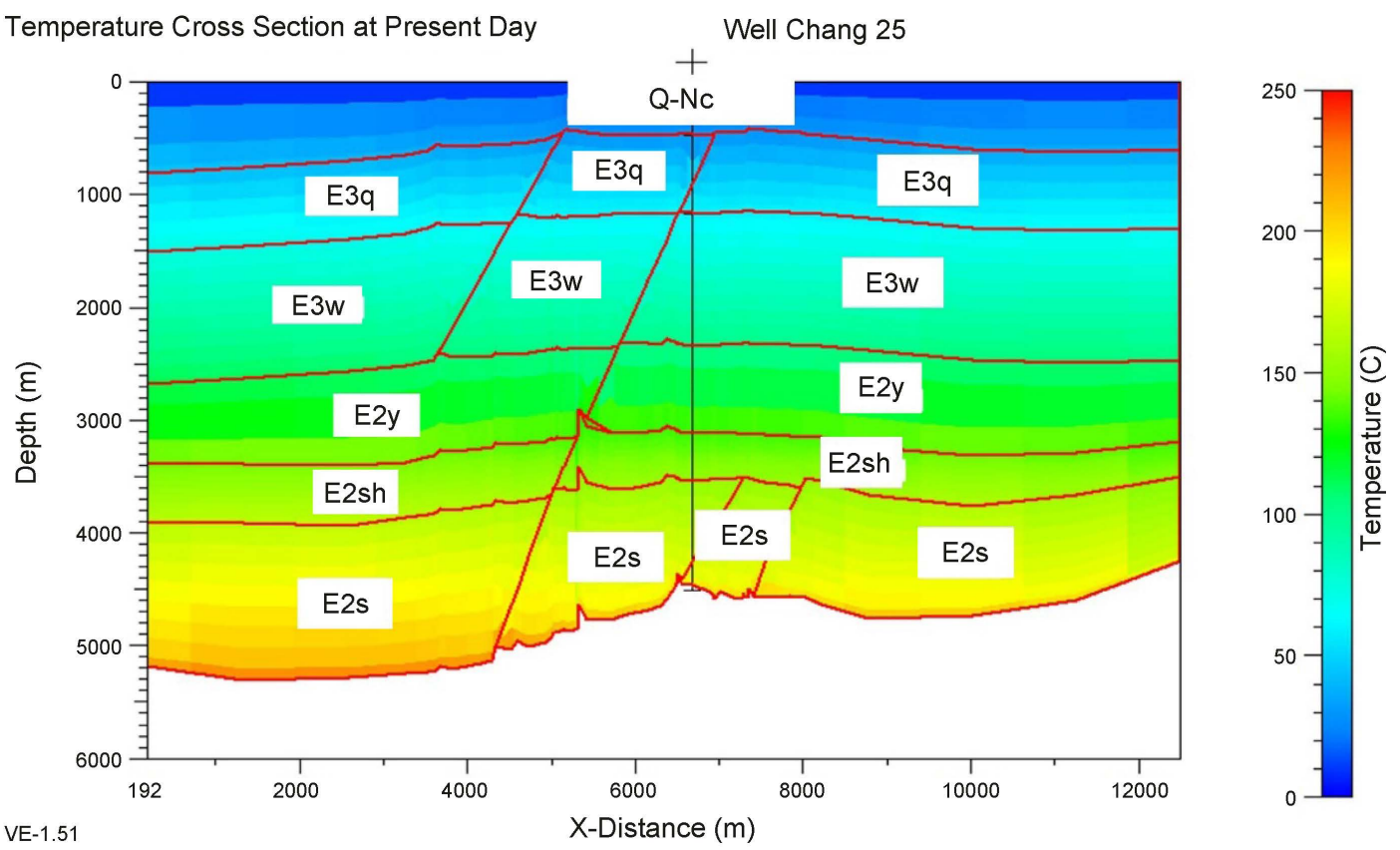

Figure 8. 2D present day temperature cross section profile of seismic line 2 . 

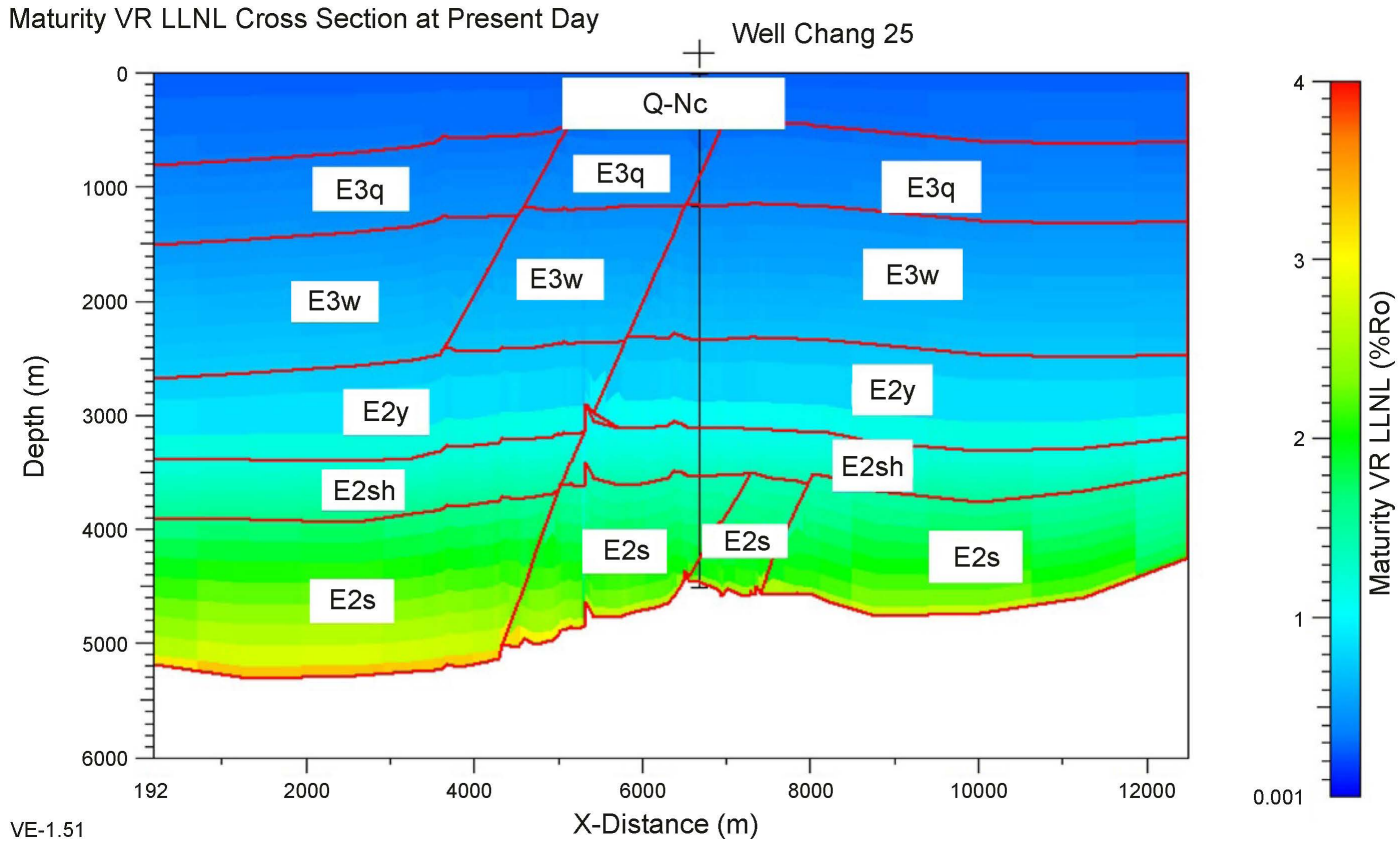

Figure 9. 2D present day maturity cross section profile of seismic line 2 .

early oil generation windows between $0.5 \%$ and $1.1 \%$ Ro, that is, entered the gas generation window and the Lower Eocene in the peak gas to late gas window. This generative potential is mainly in the Xinanpu sag of the basin.

\section{Summary and Conclusions}

In the previous chapter, two dimensional results analysis and interpretation was carried out and this chapter seeks to collate summary of all findings so that conclusive remarks could be made.

\subsection{Summary}

From Figure 5, it can be observed that the entire region from NW to SE in both source rocks are mature to produce oil and gas. At depths of about $2400 \mathrm{~m}$ and below show good maturity with vitrinite reflectance values averaging $1.02 \%$ Ro. The Bo-Tai sag of this source unit has the highest generative capability. Vitrinite Reflectance, Ro\% values reflect values between $0.73 \%$ and $1.24 \%$, Ro; well still within the Gas window if calibrated against a conventional Ro\% scale.

In Figure 7, Lower Eocene source lies within the Oil window at depths of $2400 \mathrm{~m}$ and below but enters the peak gas phase at $3217 \mathrm{~m}$ with Ro (1.3\% to $1.77 \%$ ) and the dominant source rock been the Shuangyang formations with mudstone as the source rock. The upper Eocene source thus the Sheling formation source is mainly in the oil window.

This seismic line 2 of NE to SW trending reveals from the above Figure 9, the source is mainly Upper Eocene formation. Below $2337 \mathrm{~m}$, Eocene shows early oil generation windows between $0.5 \%$ and $1.1 \%$ Ro, that is, entered the gas generation window. This generative potential is mainly in the Xinanpu sag of the basin. 


\subsection{Conclusions}

Most of the source rocks under $2000 \mathrm{~m}$ within the analyzed region are matured. Providentially, all the generated oils are expelled into the silty mudstone reservoirs in the Eocene Shuangyang formation. However, some of the source units has not generated and expelled gas. Nevertheless, the situation might not hold for the entire study area since existing geological conditions may not be the same throughout the basin.

Conclusively, exploitation of reservoirs having source units with potentially high generation and expulsion rates and quantities should be continued by well drillings.

\section{Acknowledgements}

The success of this study is down to the support in terms of financial and data from the Department of Oil and Gas exploration, Faculty of Earth Resources, China University of Geosciences (Wuhan). The Authors are grateful.

\section{References}

[1] Cao, Q., Ye, J.R., Qing, H.R., Lu, J.Z., Huang, S.B. and Tang, D.Q. (2011) Pressure Evolution and Hydrocarbon Migration-Accumulation in the Moliqing Fault Depression, Yitong Basin, Northeast China. Journal of Earth Science, 22, 351-362. https://doi.org/10.1007/s12583-011-0187-4

[2] Wang, Y.C. (2001) The Petroleum System and Accumulation in Yitong Garben. Geologic Publishing House and Petroleum Industry Press, Beijing, 143-173.

[3] Sun, W.J., Liu, B.Z. and Li, B.C. (2004) Fault System and Tectonic Style of the Yitong Graben. Geoscience, 4, 505-601.

[4] Xu, C.H., Zhou, Z.Y., Van, D.H.P., Donelick, R.A., Grave, J.D., Ma, C.Q. and Reiners, P.W. (2004) Apatite Fission Track (AFT) Chronology Study in Dabie Orogenic Belt. Science in China (Series D: Earth Sciences), 34, 622-634.

[5] Cheng, J. and Wan, T.F. (1996) On the Activity of the Tancheng-Lujiang Fault Zone during Cenozoic. Geological Science and Technology Information, 15, 35-42.

[6] Sharp, W.D. and Clague, D.A. (2006) 50-Ma Initiation of Hawaiian-Emperor Bend Records Major Change in Pacific Plate Motion. Science, 3131, 10-13. https://doi.org/10.1126/science.1128489

[7] Agbadze, O.K., Ye, J.R. and Cao, Q. (2016) One Dimensional Evolution Modeling of Source Rocks in the Chaluhe Basin, Yitong Graben. International Journal of Geosciences, 7 . 
Submit or recommend next manuscript to SCIRP and we will provide best service for you:

Accepting pre-submission inquiries through Email, Facebook, LinkedIn, Twitter, etc. A wide selection of journals (inclusive of 9 subjects, more than 200 journals)

Providing 24-hour high-quality service

User-friendly online submission system

Fair and swift peer-review system

Efficient typesetting and proofreading procedure

Display of the result of downloads and visits, as well as the number of cited articles Maximum dissemination of your research work

Submit your manuscript at: http://papersubmission.scirp.org/

Or contact ijg@scirp.org 